The

AJIAS

- ISSN-0973-4791

\title{
Effect of turmeric (Curcuma longa L.) powder supplementation on growth performance of broiler chicks in cage system
}

U.K. Shukla and Virendra Kumar Prajapati

Author for Corresponding -

U.K. Shukla

Department of Animal Science

(N.R.M.), Livestock Production

and Management, Faculty of

Agriculture, Mahatma Gandhi

Chitrakoot Gramodaya

Vishwavidyalaya, Chitrakoot,

Satna (M.P.) India

Email: Umeshdr_2006@

rediffmail.com
ABSTRACT...... The experiment was conducted at the Livestock Production and management unit, MGCGV Chitrakoot - Satna M.P.To complete the research work following steps were followed. Day old 75 broiler chicks (DOC) of same hatch were produced and reared in Cage system. The chicks were weighed, leg banded and distributed randomly into five groups of 15 chicks each as treatment. Chicks of each treatment were further divided into three sub groups of five chicks in each in Randomized Block Design ( RBD). Chicks of each sub group were accommodated comfortably in cage system providing 1 sq. ft./ chick. Chicks were fed standard starter ration upto 3 weeks age ( 1 to 21 days) and then broiler finisher ration upto 3-4 weeks (22-28 days). An experiment was conducted with DOC to 75 broilers chicks divided into five groups $\mathrm{T}_{0}, \mathrm{~T}_{1}, \mathrm{~T}_{2}, \mathrm{~T}_{3}$ and $\mathrm{T}_{4}$ which were supplemented with Turmeric powder @ $3.0 \mathrm{~g}, 4.0 \mathrm{~g}, 5.0 \mathrm{~g}$ and $6.0 \mathrm{~g} / \mathrm{kg}$ of broiler ration, respectively. Weekly observations were recorded for live body weight, weekly gain in weight, weekly feed consumption and feed conversion of birds for four Weeks. Based on the results of the experiment, it may be concluded that feed supplementation with Turmeric (Curcuma longa L.) powder influenced the body weight, gain in body weight, feed intake and feed efficiency of broiler chicks. Based on feed intake and feed efficiency (low feed intake and higher feed conversion ratio), economically best performance of broilers was obtained with $\mathrm{T}_{2}$ (feed supplementation of $4 \mathrm{~g}$ Turmeric powder with $1 \mathrm{~kg}$ standard ration), followed by $\mathrm{T}_{3}$ (feed supplementation of $5 \mathrm{~g}$ Turmeric powder with $1 \mathrm{~kg}$ standard ration).

KEY WORDS...... Broiler chicks, Growth performance, Turmeric powder

HOW TO CITE THIS ARTICLE - Shukla, U.K. and Prajapati, Virendra Kumar (2018). Effect of turmeric (Curcuma longa L.) powder supplementation on growth performance of broiler chicks in cage system. Asian J. Animal Sci., 13(2): 75-81. DOI : 10.15740/HAS/TAJAS/13.2/75-81. Copyright@ 2018: HindAgri-Horticultural Society.

ARTICLE CHRONICLE - Received : 14.09.2018; Revised : 13.11.2018; Accepted : 23.11.2018 